INTERNATIONAL JOURNAL OF

SYSTEMATIC BACTERIOLOGY

Vol. 20, No. 2

April 1970

pp. $149-153$

Copyright 1970, Iowa State University Press

\title{
ON THE IDENTITY OF MYCOBACTERIUM GORDONAE BOJALIL AND THE SO-CALLED TAP WATER SCOTOCHROMOGENES
}

\author{
Lawrence G. Wayne \\ Veterans Administration Hospital \\ San Fernando, California
}

ABSTRACT. The name "Mycobacterium aquae Galli-Valerio" has bee napplied for a number of years to slowly growing amidase negative, scotochromogenic mycobacteria isolated from tap water or clinical specimens. This name has not been validly published, and the only extant culture representing the strains originally carrying that name has been found to be a member of the rapidly growing species M. smegmatis (Gordon and Smith 1955). Examination of the type strain of $M$. gordonae Bojalil (1962) has demonstrated this organism to be very similar to the hypothetical median strain of the slowly growing "aquae" strains and these organisms should be considered members of the species M. gordonae Bojalil.

Maie, in 1922, discussed an organism he referred to as Mycobacterium aquae Galli-Valerio; implicit in this usage is the assumption that the name was previously validly published. However, not until 1927 did Galli-Valerio and Bournand employ this nomenclature (without actually proposing it even then). The descriptions of this organism given in these early papers are inadequate to permit their identification in terms of modern methods. Gordon and Smith (1955) examined the culture bearing the name $\mathrm{M}$. aquae from the original Lausanne collection, and reported it to be $\mathrm{M}$. smegmatis. Bönicke (1961), in describing slowly growing amidase negative scotochromogenic mycobacteria isolated from water taps, applied the name $M$. aquae Galli-Valerio; the organisms so described were clearly not $M$. smegmatis. Nevertheless, it thereafter became common usage to apply the name $M$. aquae to slowly growing tap water scotochromogens. 
It appears, from the brief history presented above, that the name Mycobacterium aquae has never been validly published, and even if it were, it would have to be considered a synonym of $M$. smegmatis.

A description of the Runyon Group II tap water ("aquae") scotochromogens, based on numerical taxonomic principles, was presented by Wayne et al. (1967), and the question of nomenclature was raised at that time. Recently we received the type culture of Mycobacterium gordonae Bojalil (1962) (ATCC 14470): In examining this culture, we came to the conclusion that this organism is so similar to representative tap water scotochromogens as described by Bönicke (1961) and by Wayne et al. (1967) as to be properly placed in the same species. We therefore present an additional description of the type culture of $\mathrm{M}$. gordonae Bojalil, and propose that those slowly growing scotochromogens which fit this description, and which have been called "M. aquae" or "tap water scotochromogens" in recent literature, be recognized as members of the validly published species M. gordonae Bojalil.

\section{Materials and Methods}

Culture comparisons were based on 42 characters, 30 of which have been described previously (Wayne 1966; Wayne et al. 1967). The additional 12 characters were based on tests for ability to grow at $52^{\circ}$; for resistance to 1,10 and $100 \mathrm{ug} / \mathrm{ml}$ isoniazid, to 10 and $1000 \mathrm{ug} / \mathrm{ml} \mathrm{p}$-aminosalicylate, to $10 \mathrm{\mu g} / \mathrm{ml}$ thiophene-2-carboxylic acid hydrazide, to 500 $\mu \mathrm{g} / \mathrm{ml} \mathrm{l}$-nitrobenzoic acid, to $10 \mathrm{\mu g} / \mathrm{ml}$ thiacetazone, to $5 \%$ sodium chloride, to $5 \%$ propylene glycol; for ability to blacken on egg medium containing $1000 \mathrm{ug} / \mathrm{ml} \mathrm{p}$-aminosalicylate.

Hypothetical median strain (HMS) patterns were constructed for the "tap water scotochromogens," for $M$. scrofulaceum, and for $M$. flavescens, as described by Wayne (1967). Similarity scores were then determined for the type culture of M. gordonae (ATCC 14470) against the HMS patterns for these three clusters (species) and for the HMS patterns of these clusters against one another.

\section{Results and Discussion}

Table I illustrates the percent similarities of the type culture of $\mathrm{M}$. gordonae to each of the indicated HMS patterns and of each of these patterns to one another. In this system, 
Table 1. Similarity score $(\% \mathrm{~S})$ matrix of $\mathrm{M}$. gordonae Bojalil (ATCC 14470) and Hypothetical Median Strains (HMS) of three mycobacterial species. Scores are based on 42 characters.

\begin{tabular}{lllll}
\hline & 1 & 2 & 3 & 4 \\
\hline 1. ATCC 14470 & - & & & \\
2. "Tap water" HMS & 91 & - & & \\
3. M. scrofulaceum HMS & 69 & 74 & - & \\
4. M. flavescens HMS & 48 & 57 & 60 & - \\
\hline
\end{tabular}

Wayne (1967) has indicated that species in the genus Mycobacterium tend to separate at the 80 to $85 \%$ level. M. gordonae exhibits $91 \%$ similarity to the "tap water scotochromogens," and thus falls clearly into this cluster. The name M. gordonae should therefore be applied to the species represented by this cluster. M. gordonae is clearly separated from $M$. scrofulaceum and $M$. flavescens on the basis of HMS scores of $70 \%$ or less, well below the 80 to $85 \%$ level considered significant.

In Table 2 are presented properties, based on 14 selected tests, which are most definitive in permitting characterization of and differentiation between the three species described. 
Table 2. Definitive properties of M. gordonae Bojalil (ATCC 14470) and Hypothetical Median Strain (HMS) of three mycobacterial species

\section{HMS PATTERNS OF}

\begin{tabular}{|c|c|c|c|c|}
\hline PROPERTIES & $\begin{array}{l}\text { A TCC } \\
14470\end{array}$ & $\begin{array}{l}\text { "Tap } \\
\text { water" }\end{array}$ & $\frac{\text { M. }}{\text { scrofulaceum }}$ & $\frac{\text { M. }}{\text { flavescens }}$ \\
\hline Niacin & - & - & - & - \\
\hline Tween hydrol. (5d) & d) + & + & - & + \\
\hline $\begin{array}{l}\text { Nitrate } \\
\text { reduction }\end{array}$ & - & - & - & + \\
\hline $\begin{array}{l}\text { Catalase } \\
\text { (mm foam) }\end{array}$ & $>45$ & $>45$ & $>45$ & $>45$ \\
\hline $\begin{array}{l}\text { Tween agar } \\
\text { opacity ( } 1 \mathrm{wk})\end{array}$ & - & - & - & + \\
\hline Pigment & Scoto. & Scoto. & Scoto. & Scoto. \\
\hline Benzamidase & - & - & - & - \\
\hline Urease & - & - & + & + \\
\hline Nicotinamidase & - & - & + & + \\
\hline Acetamidase & - & - & - & - \\
\hline Pyrazinamidase & - & - & + & + \\
\hline $\begin{array}{c}\text { Thiacetazone } \\
10 \mathrm{ug} / \mathrm{ml}\end{array}$ & Res. & Res. & Sens. & Res. \\
\hline Iron Uptake & - & - & - & - \\
\hline $\begin{array}{c}\text { Microcolonial } \\
\text { Neutral Red }\end{array}$ & + & + & + & - \\
\hline
\end{tabular}

* Scoto. = Scotochromogenic, i.e. pigment produced even when culture is grown in the dark. 


\section{REFERENCES}

Bojalil, L.F., J. Cerbon and A. Trujillo. 1962. Adansonian classification of mycobacteria. J. gen. Microbiol. 28:333-346.

Bönicke, R. 1961. Die Bedeutung der Acylamidasen für der Gattung Mycobacterium, Jahresbericht Borstel, Funfter Band, 7-87.

Galli-Valerio and Bornand. 1927. Le Mycobacterium aquae et son action pathogene. Zent. f. Bakt. Orig. 101:182193.

Gordon, R.E. and M. M. Smith. 1955. Rapidly growing acid fast bacteria. II. Species' description of Mycobacterium fortuitum Cruz. J. Bacteriol. 69:502-507.

Maï̈, Shin. 1922. Experimentelle Ver suche bei Goldfischen (Carassius auratus) mit saurefesten Bacillen. Zent. f. Bakt. 88:28-38.

Wayne, L.G. 1966. Classification and identification of mycobacteria. III. Species within Group III. Amer. Rev. Resp. Dis. 93:919-928.

, J.R. Doubek and G. A. Diaz. 1967. Classification and identification of mycobacteria. IV. Some important scotochromogens. Amer. Rev. Resp. Dis. 96:88-95. 